\title{
DEVELOPMENT OF A STORM RUNOFF MODEL CONSIDERING PROCESS OF INDIVIDUAL BUILDING INUNDATION
}

\author{
H. AMAGUCHI \& A. KAWAMURA \\ Deptment. of Civil and Environmental Engineering, Metropolitan University, Japan.
}

\begin{abstract}
A numerical simulation model for rainfall-runoff and flood inundation model considering process of individual building inundation was developed. The set-up of this model is based on so-called "urban landscape GIS delineation" that faithfully describes the complicated urban land use features in detail. The flow between single spatial elements is based on established hydraulic and hydrological models with equations that describe all aspects of storm runoff generation in an urban environment. The model was set up and applied for the upper Kanda catchment in Tokyo Metropolis, Japan. The runoff response to a storm event was simulated. It was demonstrated how the model can be used to evaluate the process of building inundation in the urban hydrological system.
\end{abstract}

Keywords: sewer network flow, storm runoff model, urban hydrology, urban land use GIS.

\section{INTRODUCTION}

Heavy rainfall and poor drainage facilities cause inundations in urban catchments in Japan [1]. The inundations are complex because of the problem of river overflow along with poor drainage system along rivers. Moreover, such areas are at high risk of flood damage because of the concentration of houses. As a result, not only the improvement of rainwater drainage facilities, but also assessment and review of inundation risks through inundation simulations are considered important for flood control $[2,3]$. Inundation depth is the most important parameter, and it is used for calculating the cost of damage for assessing flood control projects [4].

Simultaneous flow analysis of rainwater is generally applied in inundation models. Examples of such models include regular mesh-shaped grids, unstructured grids and street network models [5-7]. Generally, in these analytical grids, buildings are assumed to be resistant to inundation, and inundation depth is not calculated individually $[8,9]$ this is because the geographical distribution details of buildings within a ward were not available [10]. In most cases, the inundation depth of the buildings is considered the same as the calculated maximum water depth of the analytical grid $[4,10]$. For the precise evaluation of building damage, object-oriented land-use information of buildings should be evaluated, since the analytical grid enables the calculation of the water depth of buildings. Only few published studies explicitly explain the approaches for the studying individual building inundation. The lack of such studies may be attributed to the demand for detailed, local input data and the large effort required per unit area to obtain such information [4]. 
In this study, a numerical simulation model for rainfall-runoff and flood inundation model considering inundation process of individual building is developed here, which can divide the computational region into individual land use feature. Especially this model aims to treat the structure and distribution of individual buildings suitably and calculate the water depth of the buildings in a direct way.

\section{MODELLING OF BUILDING INUNDATION PROCESS}

\subsection{Urban landscape GIS delineation}

The hydrologic characteristic of an urban surface depends on its land use. The types of surfaces present ranges from the relatively impervious character of streets, parking lots and roofs, to the more pervious character of gardens, bare soil and parks. The geometric composition of these different types of surfaces that forms a block is usually complicated. This complicated and inhomogeneous nature of urban catchments makes it very difficult to model the runoff process with accuracy. However, by the use of what will be denoted "urban landscape GIS delineation," which is described in detail below, the complex configuration of urban catchments can be faithfully reproduced in a runoff model [11]. The model is thus designed to be a tool which makes it possible to simulate the flooding process in an urban catchment in a comprehensive, detailed and accurate way.

Figure 1a shows a schematic of the rainfall-runoff process as represented in the model. When rainfall begins, water falling on a land use element inside a block or a road forms pools, where water falling on a river adds to the river discharge. Rainfall excess from blocks flows out directly or indirectly through different types of surfaces and finally out into the nearest road. When a manhole exists inside the road, water flows through it to the rainwater sewer pipe conduit. When no manhole exists, water flows down the road to an adjacent road element. In a manhole, the water level is obtained considering the inflow from the road together with the upstream inflow from connected pipe conduits. In a pipe conduit, the water flow is obtained considering the water levels in the manholes located upstream and downstream, respectively. When the water level in a manhole exceeds ground level, water flows out and inundates the associated road. The inundated water either flows to adjacent road elements until a manhole that has not reached full inflow capacity is found. It may also flow into and

(a)

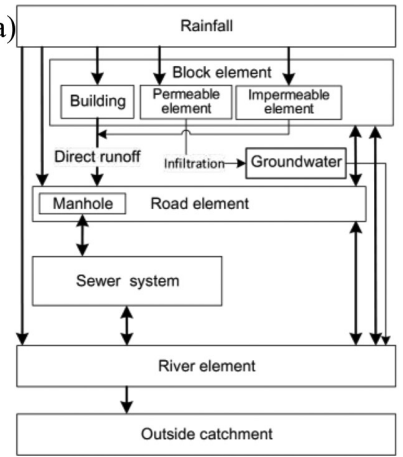

(b)

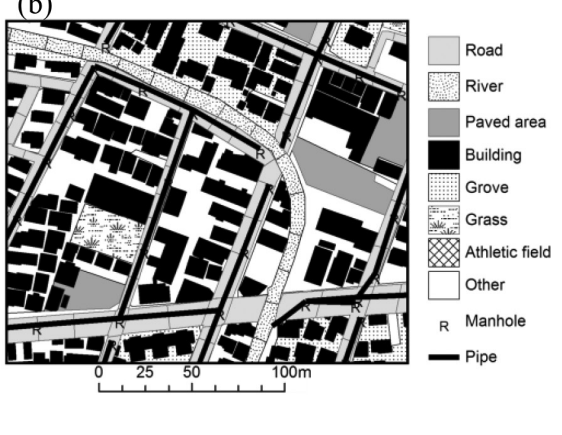

Figure 1: Schematic of the rainfall-runoff process (a) and (b) Map representing the different spatial elements considered in urban landscape GIS delineation. 
flood a block, if the water level in the road is higher than that in the block. The water in the sewer pipe conduits eventually reaches the river channel, which finally drains in the catchment outlet. Infiltrated water from pervious land use elements inside blocks finally drains out into the river as long-term groundwater runoff, which is however at present not considered in the model.

\subsection{Model equations}

\subsubsection{Direct runoff}

Figure 2 shows the schematic of urban landscape GIS delineation and the assumed flow processes. In land use segments inside block elements, direct runoff from a non-building segment to an adjacent block segment is assumed. The direct runoff on a building segment is as follows. Although rainfall on buildings usually runs off to the sewer system through a gutter, it is rare to have information on the connection between a building and the sewer system. In model, the kinematic wave model [12] is applied to calculate the flow from a building segment to the nearest road or river segment eqns (1) and (2). Since the actual shapes of individual buildings are sometimes complicated, the shape (flow distance $x_{b}$ and flow width $B$ ) is supposed to be square with the same size as the actual segment.

$$
\begin{gathered}
\frac{\partial h_{b}}{\partial t}+\frac{\partial q_{b}}{\partial x_{b}}=r_{e} \\
q_{b}=\alpha h_{b}^{\beta}\left(\alpha=\sqrt{\sin \theta} / \mathrm{N}_{\mathrm{b}}, \beta=5 / 3\right)
\end{gathered}
$$

where $q_{b}$ denotes the discharge per unit width from the building $\left(\mathrm{m}^{2} / \mathrm{s}\right), h_{b}$ the flow depth (m) and $x_{b}$ the distance along the building (m). In (2), $\alpha$ and $\beta$ are constants related to slope and overland roughness, $\theta$ the slope of the building (rad) and $N_{b}$ is the equivalent Manning's roughness coefficient $\left(\mathrm{s} / \mathrm{m}^{1 / 3}\right)$. Rainfall intensities in excess of the final infiltration capacity become effective rainfall eqn (3).

$$
r_{e}(t)=r(t)-I_{i}
$$

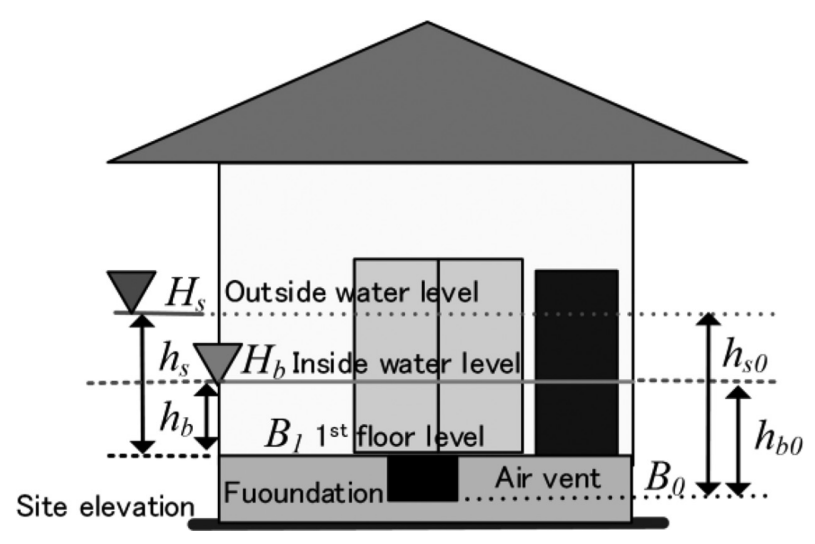

Figure 2: Parameters used for building inundation. 


\subsubsection{Overland flow}

To calculate the discharge in overland component, one-dimensional unsteady flow without convective acceleration is assumed according to eqn (4). Water level changes in the overland segments are computed by considering the effective rainfall and outflow/inflow from manhole elements in addition to the outflow/inflow from overland segments. After calculating water storage, the water depth is obtained by eqn (5)

$$
\begin{gathered}
\frac{\partial Q_{s}}{\partial t}+g A_{s} \frac{\partial H_{s}}{\partial x_{s}}+\frac{g n_{s}^{2} Q_{s}\left|v_{s}\right|}{R_{s}^{4 / 3}}=0 \\
\frac{d h_{s}}{d t}=\frac{\Sigma Q_{s}+\Sigma B q_{b}+\Sigma Q_{d i v}+r_{e} \text { Area }_{s}}{\text { Area }_{s}}
\end{gathered}
$$

where $Q_{s}$ is the overland discharge $\left(\mathrm{m}^{3} / \mathrm{s}\right), A_{s}$ the overland flow cross sectional area $\left(\mathrm{m}^{2}\right)$, $H_{s}\left(=z_{s}+h_{s}\right)$ the overland water level $(\mathrm{m}), z_{s}$ the overland elevation $(\mathrm{m}), h_{s}$ the overland water depth $(\mathrm{m}), x_{s}$ the longitudinal distance along overland segment $(\mathrm{m}), n_{s}$ the overland Manning's roughness coefficient $\left(\mathrm{s} / \mathrm{m}^{1 / 3}\right), v_{s}$ the velocity of overland flow $(\mathrm{m} / \mathrm{s}), R_{s}$ the overland hydraulic radius (m), $B$ the width of building segment (m), $Q_{d i v}$ the discharge to/from manhole from/to overland $\left(\mathrm{m}^{3} / \mathrm{s}\right)$ and Area $_{s}$ the overland area $\left(\mathrm{m}^{2}\right)$ (excluding the building area in block segments). The numerical analysis technique used for the overland flow, as well as for the calculations of sewer pipe flow and river flow described below, is the unsteady flow equation by the explicit finite difference method.

\subsubsection{Building inundation}

In order to calculate the building inundation depth, buildings in the block element are used for the analysis of the overland flow and the flow to the buildings is considered based on the water level around the buildings eqn (6). Figure 3 shows the parameters used in the model.

$$
Q_{b 0}=\left\{\begin{array}{cc}
\mu_{1} L \alpha_{0} h_{s 0} \sqrt{2 g h_{s 0}} & \left(h_{b 0} / h_{s 0} \leq 2 / 3\right) \\
\mu_{2} L \alpha_{0} h_{b 0} \sqrt{2 g\left(h_{s 0}-h_{b 0}\right)} & \left(h_{b 0} / h_{s 0}>2 / 3\right)
\end{array}\right.
$$

where $Q_{b}$ is the flow from the surrounding features to building $\left(\mathrm{m}^{3} / \mathrm{s}\right)$, and are flow coefficients, is the opening ratio below the 1 st floor, is the opening ratio above the 1 st floor, and $L$ is the outer perimeter of the building $(\mathrm{m})$. In addition, $h_{b}$ is the indoor inundation height above the 1 st floor $\left(=H_{\mathrm{b}}-B_{1}\right), h_{s}$ is the outdoor water height above floor $\left(=H_{\mathrm{b}}-B_{1}\right)$. The same height applies to the water level to the underfloor air vacant, and $h_{\mathrm{b} 0}$ is the indoor inundation height $\left(=H_{\mathrm{s}}-B_{0}\right), h_{\mathrm{s} 0}$ is the outdoor inundation height $\left(=H_{\mathrm{s}}-B_{0}\right)$. The overflow equation is used for the discharge from/to a building. The inundation depth in the building is calculated by eqn (7).

$$
\frac{d h_{b}}{d t}=\frac{\left(\sum Q_{b 0}+\sum Q_{b}\right)}{0.9 A_{b}}
$$

where, $A_{b}$ denotes the building roof area which is obtained from the urban landscape GIS. In this study, we assume the floor area is approximately $90 \%$ of the roof area. 
(a)

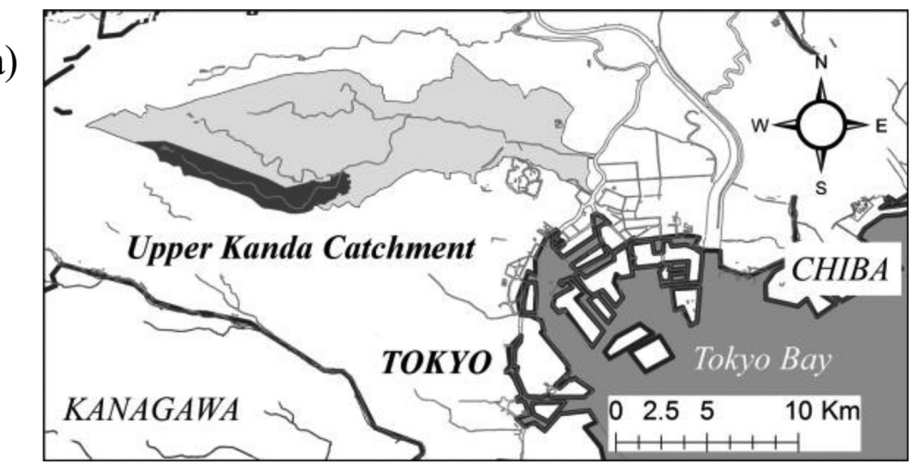

(b)

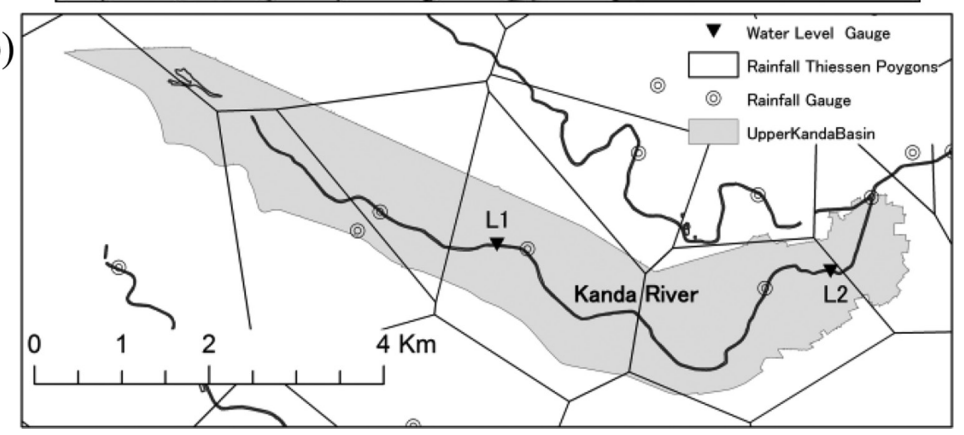

Figure 3: Location of the upper Kanda catchment in Tokyo and (a) and overview of the upper Kanda catchment selected for model application (b).

\subsubsection{Sewer pipe flow}

The runoff in a sewer is usually in the state of free surface flow. However, in the case of a storm, both free surface flow and surcharged flow occur, and their regions vary temporally and spatially. In order to describe these processes in detail, a particular model for sewer pipe flow with surcharge is required and here dynamic waves are used to describe both free surface flow and surcharged flow. For the surcharged flow, the technique based on the assumption of a hypothetical slot is applied [13]. The equation of motion without convective acceleration and continuity of the slot model is applied as

$$
\frac{\partial Q_{p}}{\partial t}+g A_{p}\left(\frac{\partial H_{m}}{\partial x_{p}}\right)+\frac{g n_{p}^{2} Q_{p}\left|v_{p}\right|}{R_{p}^{4 / 3}}=0
$$

where $Q_{p}$ is the pipe discharge $\left(\mathrm{m}^{3} / \mathrm{s}\right), A_{p}$ the pipe flow cross sectional area $\left(\mathrm{m}^{2}\right), H_{m}$ the manhole water level $(\mathrm{m}), x_{p}$ the distance along pipe $(\mathrm{m}), n_{p}$ the pipe Manning's roughness coefficient $\left(\mathrm{s} / \mathrm{m}^{1 / 3}\right), v_{p}$ the velocity of pipe flow $(\mathrm{m} / \mathrm{s}), R_{p}$ the pipe hydraulic radius $(\mathrm{m})$.

In a manhole, the storage quantity and water level are calculated by eqn (9) and eqn (10) respectively. The storage is based on the size of the manhole and its connection according to

$$
\frac{d S_{m}}{d t}=\sum Q_{d i v}+\sum Q_{m}
$$




$$
H_{m}=f_{m h}\left(S_{m}\right)
$$

where $S_{m}$ is storage quantity in a manhole and connected pipe $\left(\mathrm{m}^{3}\right), Q_{m}$ the flow from/to the connected pipe $\left(\mathrm{m}^{3} / \mathrm{s}\right)$ and $f_{m h}$ a function relating storage to water level in the manhole $(\mathrm{m})$.

When the water level in a manhole exceeds ground water level, water flows out and inundates the associated overland segment. The discharge between a manhole and a overland segment is evaluated according to

$$
Q_{d i v}=\left\{\begin{array}{cc}
\frac{f_{m v}\left(H_{m}\right)-f_{m v}\left(H_{s}\right)}{d t} & \text { (outflow from manhole) } \\
\mu \text { Area }_{m} \sqrt{g \Delta h_{s}} & \text { (inflow to manhole) }
\end{array}\right.
$$

where $f_{m v}$ is a function relating manhole water level to volume,$\mu$ a coefficient and Area $_{m}$ the manhole area.

\subsubsection{River flow}

The river channel flow considering the inflow from the rainfall and sewer pipes, as well as the side inflow from overland segments, is calculated by the equations of motion and continuity as

$$
\begin{gathered}
\frac{\partial Q_{r}}{\partial t}+\frac{\partial\left(Q_{r}{ }^{2} / A_{r}\right)}{\partial x_{r}}+g A_{r} \frac{d H_{r}}{d x_{r}}+g \frac{n_{r}{ }^{2} Q_{r}\left|v_{r}\right|}{R_{r}^{4 / 3}}=0 \\
\frac{\partial A_{r}}{\partial t}+\frac{\partial Q_{r}}{\partial x_{r}}=q_{r}
\end{gathered}
$$

where $v_{r}$ is the velocity of the river flow $(\mathrm{m} / \mathrm{s}), x_{r}$ the distance along river channel $(\mathrm{m}), \mathrm{H}_{r}$ the river water level $(\mathrm{m}), n_{r}$ river Manning's roughness coefficient $\left(\mathrm{s} / \mathrm{m}^{1 / 3}\right), R_{r}$ the river channel hydraulic radius (m), $A_{r}$ the river flow cross sectional area $\left(\mathrm{m}^{2}\right)$ and $q_{r}$ the cumulative discharge from sewer system and overland segments to river segment in addition to rainfall ( $\left.\mathrm{m}^{3} / \mathrm{s}\right)$.

\section{APPLICATION TO THE UPPER KANDA CATCHMENT}

\subsection{Study area}

The study area selected for the model application is an urban catchment, which is located in the Kanda catchment Tokyo Metropolis, Japan, as shown in Fig. 4a. The study catchment will be termed "upper Kanda catchment" and Fig. 4b shows this catchment in some detail. The boundary of the study catchment is specified based on two conditions, the topography and the extension of the sewer pipe network. The upper Kanda catchment area is $\sim 11 \mathrm{~km}^{2}$ and the length of river inside it is $\sim 10 \mathrm{~km}$. It is essentially a residential area with some minor parks, groves, fields, etc. There are several water level gauges and rainfall gauges in the catchment. Concerning the land use, $\sim 65 \%$ of the surface is impervious. Rainfall from the upper part of the Kanda river reaches the study catchment only by gravity flow through the combined sewer system. There is a main sanitary sewer along the Kanda River. During intense storms, this sewer soon flows full and discharges downstream of the catchment, which makes the catchments vulnerable to flooding. Concerning rainfall and runoff observation, there are seven rainfall gauges around catchment, where observations are made with a 1-min time resolution 


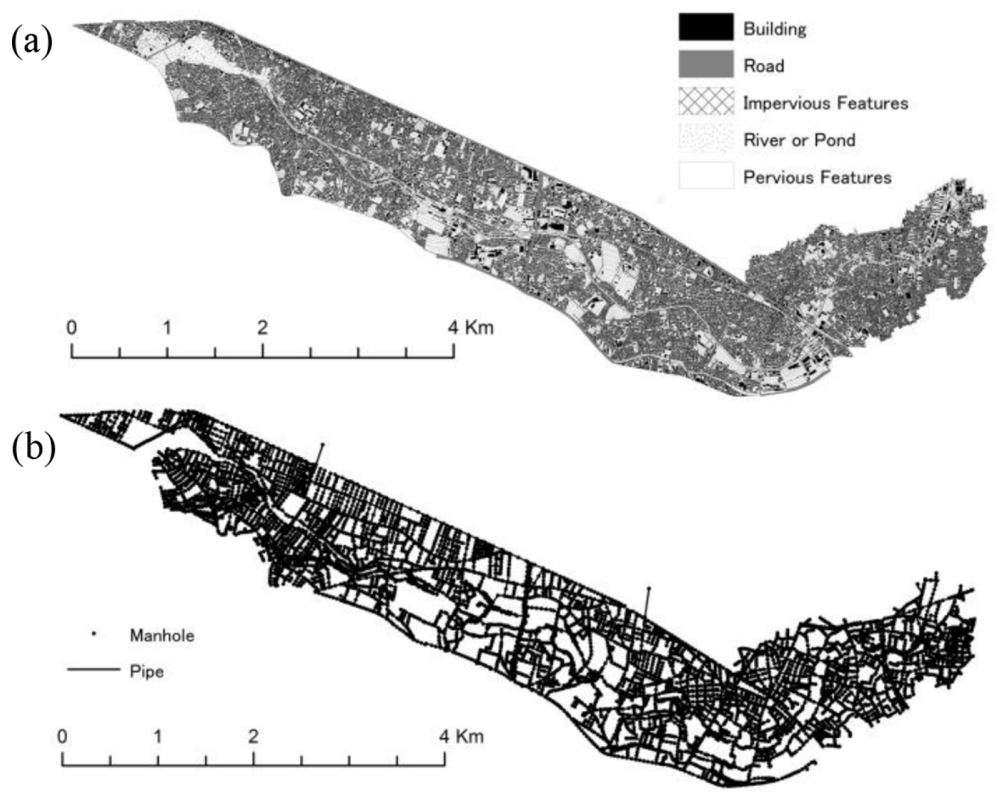

Figure 4: Final map of overland component (a) and sewer element (b) in the upper Kanda catchment.

by Tokyo Metropolitan Government. Fig. 3 shows the final maps of overland component (a) and sewer element with road, block and river segments (b) in the entire study catchment. It should be emphasized that more than 180000 homogeneous elements (land use, road, river, manhole and pipe) were used to completely specify the urban catchment.

\subsection{Application condition}

Table 1 gives the parameters of the model for the building inundation process. The ground level of each building was calculated as an averages obtained from a $5 \mathrm{~m}$ DEM with $0.1 \mathrm{~m}$ precision in elevation, with $0.1 \mathrm{~m}$ added to that value to set the elevation of the building. The floor height and water intrusion rate of a building can have significant impact on the risk of building inundation. Therefore, we classified buildings into residential houses and non-residential buildings, such as commercial facilities and factories, in order to approximate differences in building accessibility. For residential houses, the Japanese building standards stipulate that the height of the foundation should be at least $45 \mathrm{~cm}$ above the ground surface elevation, and underfloor ventilation holes of $300 \mathrm{~cm}^{2}$ in cross-sectional area should be installed at least every $5 \mathrm{~m}$ along the foundation [14]. The height of the foundation is assumed to be $50 \mathrm{~cm}$ in our model, while that of the ventilation holes is assumed to be 10 $\mathrm{cm}$ from the top of the foundation with a width of $30 \mathrm{~cm}$ every $5 \mathrm{~m}$ in foundation length. As a result, the opening ratio below the 1 st floor is $6 / 100(=0.3 / 5.0)$. For factories, commercial facilities and other non-residential use buildings, the height of the 1st floor is assumed to be $25 \mathrm{~cm}$. The foundation height of buildings with basement rooms is assumed to be $3 \mathrm{~m}$ in depth below the site elevation.

Table 2 gives the parameters required by the model. Only standard values 
Table 1: Parameter of the building inundation model.

\begin{tabular}{lccc}
\hline & Wooden & Non-wooden & Commercial use \\
\hline$B_{0}$ & $+40 \mathrm{~cm}$ & - & - \\
$B_{1}$ & $+50 \mathrm{~cm}$ & $+50 \mathrm{~cm}$ & $+25 \mathrm{~cm}$ \\
$a_{0}$ & $6 / 100$ & - & - \\
$a_{1}$ & $6 / 100$ & $2 / 100$ & $2 / 100$ \\
Numbers of elements & 2,449 & 28,708 & 2,893 \\
Total Area $\left(\mathrm{m}^{2}\right)$ & 188,919 & $2,601,434$ & 273,530 \\
\hline
\end{tabular}

Table 2: List of required input data and parameters of the model.

\begin{tabular}{llc}
\hline Parameter (Unit) & & Value \\
\hline Initial infiltration & Green space & 30 \\
capacity $(\mathrm{mm} / \mathrm{hr})$ & Others & 10 \\
$\begin{array}{l}\text { Final infiltration } \\
\text { capacity }(\mathrm{mm} / \mathrm{hr})\end{array}$ & Green space & 20 \\
$\begin{array}{l}\text { Building roughness } \\
\text { coefficient } n_{b}\left(\mathrm{~s} / \mathrm{m}^{1 / 3}\right)\end{array}$ & Others & 5.0 \\
$\begin{array}{l}\text { Overland roughness } \\
\text { coefficient } n\left(\mathrm{~s} / \mathrm{m}^{1 / 3}\right)\end{array}$ & Between roads & 0.035 \\
$\begin{array}{l}\text { Channel roughness } \\
\text { coefficient } n\left(\mathrm{~s} / \mathrm{m}^{1 / 3}\right)\end{array}$ & & 0.043 \\
Pipe roughness & & 0.067 \\
coefficient $n\left(\mathrm{~s} / \mathrm{m}^{1 / 3}\right)$ & & 0.0225 \\
\hline
\end{tabular}

were used in this study, and no attempt was made to adjust the parameter values is made but standard values are used [5, 15-17].

\subsection{Simulation of actual storm events}

To test the applicability of the model for storm runoff analysis, simulations were performed for two historical storm events. The first represents a small scale event in October 2004, during which the storm water runoff in the sewer system was mainly free surface flow and no inundation occurred. The second represents a flooding event that followed heavy rainfall caused by typhoon no. 14 (Nagi) in September 2005. Although there was no significant inundation damage in the upper Kanda catchment, due to the use of an underground retention basin for the river, we evaluated the building inundation model using inundation characteristics assumed in the absence of the underground retention basin.

In the simulations, the initial water levels and discharge in the river channel were set at steady-state conditions, after an adequate model warm-up period for the calculations to attain stability, during which river flow was calculated using the first water level observation in each event. The initial flow in the sewer system, overland component was set to zero. The water level at the catchment outlet was estimated from the calculated discharge using the outlet rating curve. 


\subsection{Results}

The validity of the model was judged using the water levels in river channels. Observed and simulated water levels at gauge locations L1 and L2, together with the observed rainfall during the first storm event, are shown in Fig. 5a and b. The calculated and observed discharges are in good overall agreement at these two locations, although no calibration or tuning of model parameters was performed. Also the runoff peak is generally well reproduced, although it is underestimated by $4 \mathrm{~m}^{3} / \mathrm{s}$ at gauge L2. Overall, the accuracy and trends in the simulated data were very similar to the observed discharge data.

In order to also evaluate the model's ability to reproduce inundated conditions, a second simulation was performed using the major storm event that occurred on 2005-09-04. The maximum observed 1-h rainfall volume was $112 \mathrm{~mm}$ within the Kanda catchment.

Figure $5 \mathrm{c}$ and $\mathrm{d}$ show observed and calculated river water levels at L1 and L2. The observed water level at L1 is lowered intermittently because of the inflow to the retention basin. Overall, the simulated levels, including the peak water level agree with the observed levels, although the initial rise time of the simulated water level is 20 minutes earlier than that of the observed water levels. There was no difference between the model and a conventional model without considering the process of individual building inundation in terms of simulated river water levels.

In the simulation, to evaluate the area affected by building inundation, the distribution of the maximum inundation depth in the catchment was determined. A sample map of the maximum inundation depth near the river channel is shown in Fig. 6. The symbol inside the building denotes whether it is intended for residential or commercial use. In the proposed model, which employs the explicit process of building inundation, rainwater is assumed to flow into residential houses through ventilation holes in the foundation, which are set $40 \mathrm{~cm}$ higher than the site elevation. We found that residential buildings are inundated when the
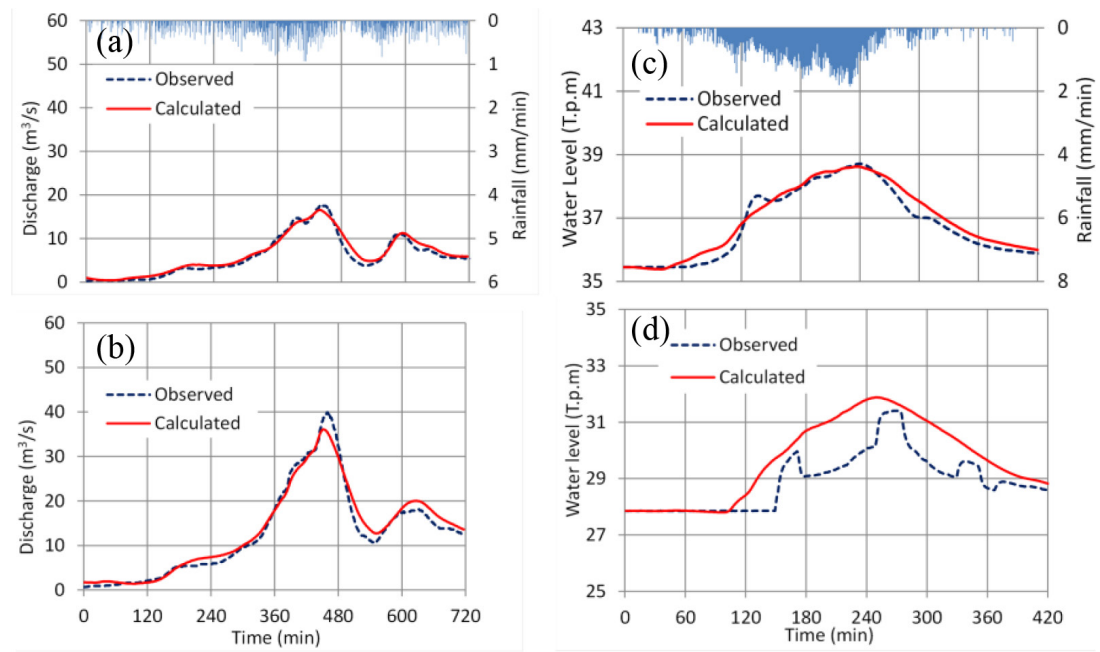

Figure 5: Observed and simulated river discharge in gauges L1 (a) and L2 (b) during event 2004/10/9 and Observed and simulated river water level in gauges L1 (c) and L2 (d) during event 2005/9/4. 
(a)

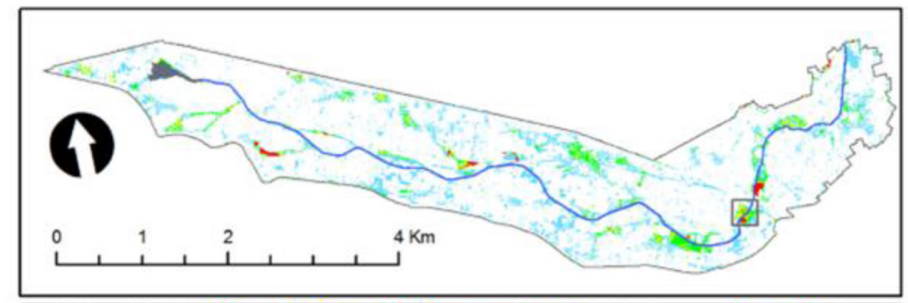

(b)

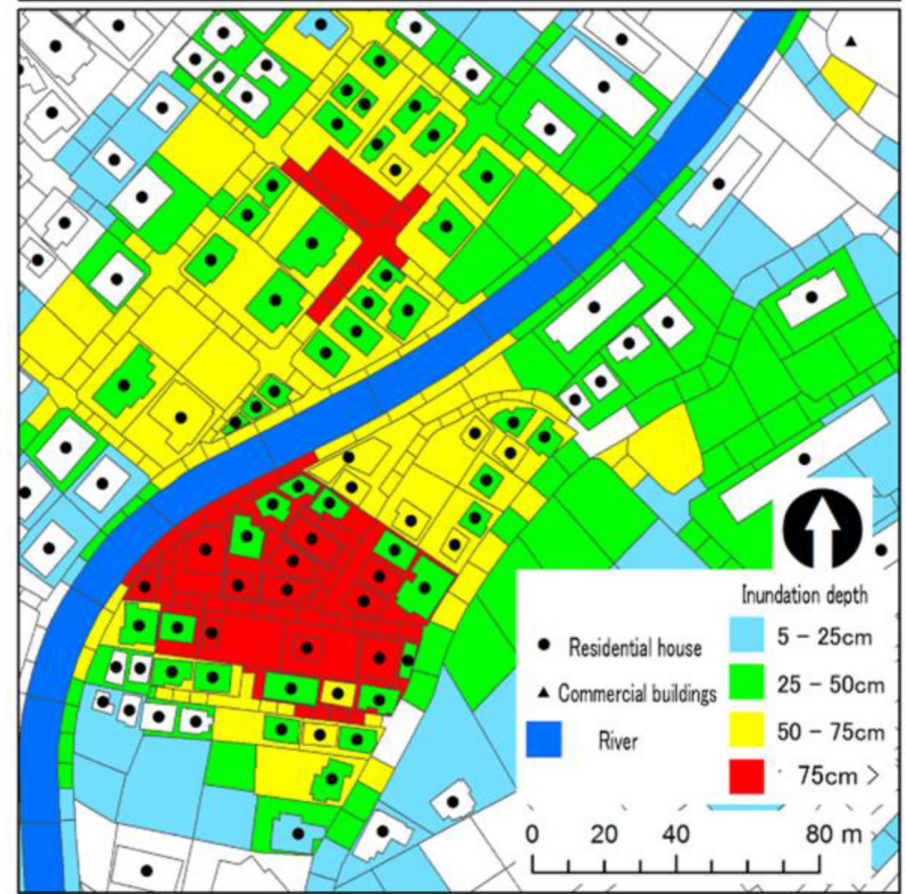

Figure 6: Distribution of maximum inundation depths (a) Overall vies, (b) Expanded view.

maximum inundation depth of their surroundings is in the range of $25-50 \mathrm{~cm}$. As the inundation depth increases from 50 to $75 \mathrm{~cm}$ and exceeds $75 \mathrm{~cm}$, the inundation depth of the buildings also increases gradually. This means that in this simulation, the space under the floor of residential houses does not get flooded unless the water level around these buildings exceeds $40 \mathrm{~cm}$. In conventional modelling approaches which are usually based on regular mesh-shaped grids, unstructured grids and street network data $[5,6,10]$, the inundation depth of the building is usually set the same as that of the analytical cell, and hence, there is a tendency to overestimate the inundation risk of buildings as compared to the proposed model.

\section{SUMMARY AND DISCUSSION}

In this study, a numerical simulation model for rainfall-runoff and flood inundation was developed; this model considers the inundation process of individual building. The model was built and evaluated for the upper Kanda catchment, Tokyo Metropolis, Japan. In the model, the parameters for the foundation height and floor height of each building and the opening ratio below and above the 1 st floor were set for individual buildings based on their 
structure and purpose. The model was applied to simulate one major storm event. It could reproduce differences in the inundation depth of individual buildings reflecting the additional input parameters. The use of the model to evaluate the inundate condition for specific properties of the building was also demonstrated.

Overall, the results show that the suggested approach, which is based on a detailed reproduction of all relevant elements in an urban catchment, can simulate the process of individual building inundation. Although in principle, the approach is relatively straight-forward, it has been developed and applied practically until now because of limitations in GIS data availability. We believe the methodology has a wide range of applications with regard to improving flood protection facilities and installing new runoff control facilities. Another potential use of the model is detailed urban impact assessment of the higher rainfall intensities that are expected to occur more frequently in the near future. The condition at specific critical locations can be easily extracted from the model output and used for flood risk assessment.

\section{REFERENCES}

[1] Kawata, Y., Urban flood control policy for sustainability under global warming in Japan. First International Conferences on Flood Recovery, Innovation and Response, pp. 273-282, 2008.

http://dx.doi.org/10.2495/friar080261

[2] Andjelkovic, I., Guidelines on non-structural measures in urban flood management. International Hydrological Programme, technical document in Hydrology, No. 50, 2001.

[3] Genovese, E., A methodological approach to land use-based flood damage assessment in urban areas: prague case study. Mission of the Institute for Environment \& Sustainability, European Commission, 2006.

[4] Merz, B., Kreibich, H., Schwarze, R. \& Thieken, A., Review article assessment of economic flood damage. Natural Hazards and Earth System Sciences, 10, pp. 1697-1724, 2010. http://dx.doi.org/10.5194/nhess-10-1697-2010

[5] Inoue, K., Kawaike, K. \& Toda, K., Refuge analysis under storm surge based on the street network model. Proceeding of the International Symposium on Flood Cont, Beijing, China, pp. 507-514, 1999.

[6] Kawaike, K., Inoue, K. \& Toda, K., Inundation flow modelling in urban area based on the unstructured meshes. Hydraulic Engineering Software VIII, eds. C.A. Brebbia \& W.R. Blain, WIT Presss, 2000.

[7] Dey, A.K. \& Kamioka, S., An integrated modeling approach to predict flooding on urban basin. Water Science \& Technology, 55(4), pp. 19-29, 2007. http://dx.doi.org/10.2166/wst.2007.091

[8] Schubert, J.E. \& Sanders, B.F., Building treatments for urban flood inundation models and implications for predictive skill modelling efficiency. Advances in Water Resources, 41, pp. 49-64, 2012.

http://dx.doi.org/10.1016/j.advwatres.2012.02.012

[9] Chang, T., Wang, C. \& Chen, A.S., A noble approach to model dynamic flow interaction between storm sewer system and overland surface for different land covers in urban area. Journal of Hydrology, 524, pp. 662-679, 2015.

http://dx.doi.org/10.1016/j.jhydrol.2015.03.014

[10] Dutta, D., Herath, S. \& Musiake, K., A mathematical model for flood loss estimation. Journal of Hydrology, 277, pp. 24-49, 2003.

http://dx.doi.org/10.1016/S0022-1694(03)00084-2 
[11] Amaguchi, H., Kawamura, A., Ollson, J. \& Takasaki, T., Development and testing of a distributed urban storm runoff event model with a vector-based catchment delineation. Journal of Hydrology, 420-421, pp. 205-215, 2012. http://dx.doi.org/10.1016/j.jhydrol.2011.12.003

[12] Singh, M.B., Kinematic Wave Modelling in Water Resources, John Wiley \& Sons: USA, 1996.

[13] Preissmann, A. \& Cunge, J.A., Calcu des Intumescences sur Machinas Electroniques. Proceeding 9th Congress of IAHR, Dubrovnik, Yugoslavia, pp. 656-664, 1961.

[14] Japanese Ministry of Internal Affairs and Communications, order for enforcement of the building standards act, available at http://law.e-gov.go.jp/htmldata/S25/S25SE338. html

[15] Ando, Y., Takahashi, Y., Izumi, K. \& Kanno, K., Urban flood modeling considering infiltration various land uses. In Urban Drainage Modelling, eds. C. Maksimović \& M. Radojković, pp. 229-238, Pergamon press: Oxford, England, 1986.

[16] Yen, B.C., Hydraulic resistance in open channel. In Channel Flow Resistance: Centennial of Manning's Formula, ed. B.C. Yen, pp. 1-135, Water Resour. Pub.: Colorado. USA, 1991.

[17] Mays, L.W., Water Resources Engineering, John Wiley and Sons: USA, 2001. 